\title{
REVISITING THE PUBLIC-PRIVATE DIVIDE: WORKPLACE VIOLENCE AND THE US FOREST SERVICE
}

Kindra Ramble

\begin{abstract}
The Oklahoma City bombing put a sensational face on antigovernment violence. Yet, for all of the attention devoted during its aftermath to the growth and possible consequences of antigovernment sentiments, little systematic investigation has been done regarding the extent to which this type of violence may have permeated the government workplace. Further, scholars presently lack contextual knowledge about potential differences between public sector and private sector workplace violence in which to place hypotheses concerning the connections between antigovernment sentiments and the violent victimization of government employees. This article probes those connections through a study of the workplace violence endured by rangers of the United States Forest Service, in hopes of contributing to the understanding of the complicated relationships between workplace violence, antigovernment activity, and employment in the public sector. Analysis of the violent incidents uncovered through this study lends support to the conclusion that violence waged against government employees is significantly different than the violence being perpetrated in private sector work settings. These findings furcher suggest that antigovernment activity contributes meaningfully to the differences in workplace violence experienced by government employees.
\end{abstract}

OnAugust 4, 1995, two bombs exploded in Carson City, Nevada. One blew the front window out of a bome belonging to a forest ranger; the other destroyed his van. Just one month prior, a ranger in California had been shot seven times with a 38-caliber handgun after pulling a motorist's vehicle to the side of the road. In Klamath Falls, Oregon, a female ranger was beaten by two unknown women. During the assault, her assailants made disparaging remarks about her employment with the Forest Service. Bombs have detonated on Forest Service property in New Mexico, Nevada, Arizona, and Washington State. Some have completely leveled Forest Service facilities. Bomb threats, as well as other threats of violence, have been called into Forest Service buildings and ranger stations in numerous additional locations. After one such threat, armed guards were placed at the doomway of a Forest Service building in Ogden, Utah. In November of 1996, two unknown men fired on a uniformed ranger who was, at the time, driving a clearly marked Forest Service vehicle.

Kindra Ramble holds a Bachelor of Arts degree in Political Science and in Society and Justice from the University of Washington, Seattle. She is a Master of Public Administration candidare at The George Washingron University in Washington, $D C$.
Unfortunately, the incidents above only begin to describe the violence directed at rangers of the United States Forest Service (USFS). Like other victims of workplace violence, forest rangers have suffered both overt threats of violence and physical assault on the job. However, while rates of workplace violence have declined nationally, ${ }^{1}$ violence against rangers does not appear to be subsiding. By some estimates, it may even be on the rise. ${ }^{2}$ To what can this difference be attributed? The findings presented in this article suggest that workplace violence perpetrated against forest rangers follows a pattern unlike that experienced by others in the American workforce, and point to their status as public employees as one aspect of the explanation for the differences. The findings presented here additionally imply an important link between violence borne out of persistent antigovernment sentiments and patterns of workplace violence. While it remains to be seen if future research will support these connections, suggestive evidence of their relevance can be drawn from both anecdotal and theoretical sources. In this regard, it is somewhat perplexing that scholars from both public administration and criminology have only begun to explore the relationships between the public service, workplace violence, and antigovernment activity, as well as the implications of these relationships for individual public employees and our notions of governance alike.

\section{Public Administrators are "Different"}

A considerable body of literature has been dedicated to the exploration of differences between public and private sector employees. Out of this body of literature has emerged the generally accepted proposition that private sector employees and public administrators are, in certain important

Policy Perspectives, Fall 1999 (Volume 7 Number 1) (C) 1999 The George Washington University 
respects, different. Most often, the differences between public administrators and private employees are described in terms of their respective attitudes and orientations, the nature of their "missions," and the visibility of their actions.

For example, Appleby, ${ }^{3}$ Allison, ${ }^{4}$ and Holtz and Callahan ${ }^{5}$ have suggested that public administrators are far more equity or care-oriented than their private sector counterparts, indicative perhaps of a difference closely tied to the decision to pursue employment serving the public. In addition, Allison " and Mosher" have both pointed out that government employees derive their authority from sources different than those at work in the private sector, and as a result, experience levels of legislative, media, and public scrutiny not typically experienced by employees in the private sector. Finally, as Goodsell suggests, government employees are charged with the responsibility of dealing with tasks and clientele so removed from a profit-driven perspective that the private sector often "would not touch or has abandoned" them. ${ }^{8}$ Collectively, these differences are suggestive of important work-related distinctions between public administrators and private employees.

However, it is at least possible that the identified differences between public administrators and their private sector counterparts are not constitutive of a complete picture of their dissimilarity. The possibility of one "new," or at least newly identified, potential difference has started to receive scholarly attention. Specifically, scholars from public administration and criminology have begun to examine differences related to the frequency, severity, and motives characterizing the workplace violence occurring in public versus private sector work settings." Perhaps because attention to these potential differences has only recently emerged (many scholars seemingly inspired to some degree by the devastating violence of the 1995 Oklahoma City Bombing), research on violence in the public sector workplace in particular remains speculative. Compounding this newness is the youth of workplace violence study in general, which has until now mainly focused on private sector work settings, and only developed as an extant area of study during the last two decades. As a result, little has been said definitively about the nature of public versus private workplace violence.

However, recollections of the rageful, antigovernment bombing in Oklahoma seem reason enough to warrant additional inquiry into the area of violence in the government workplace. During this time, which King and Stivers have labeled the "anti-public administration era," "I" students of the bureaucracy and criminologists alike should evaluate whether or not an additional correlate of public service is the enhanced potential for any variety of violent victimization in the workplace. It is with an eye to these considerations, the newness of visible terrorist-like violence against government employees, heightened concerns about a possible spread of antigovernment sentiments, and the potential consequences of a superficial understanding of workplace violence occurring in the public sector, that this article is intentioned. It is the aim of this study to contribute to the emerging body of knowledge about violence in the public workplace, as well as to the literature describing the uniqueness of the public service, via a careful examination of the nature of violence perpetrated against USFS Rangers.

\section{Violence in the Workplace: Do Differences Exist Between Public and Private Sector Settings?}

Data describing violence in the workplace are collected each year by the National Crime Victimization Survey (conducted jointly by the Bureau of the Census and the Bureau of Justice Statistics, and hereafter referred to as the NCVS) as well as by the FBI's Uniform Crime Report (UCR). Existing studies of workplace violence have largely drawn from statistical data gathered by these two sources. These studies suggest that while the number of incidents of workplace violence has increased since the $1980 \mathrm{~s},{ }^{11}$ rates of workplace violence may vary with the overall rate of violent crime. Support for this correlation is implicit in available statistics on rates of workplace violence, which (like the violent crime rate) escalated through the late $1980 \mathrm{~s}$ and into the early $1990 \mathrm{~s}$ before declining dramatically, beginning in $1995 .^{12}$ NCVS data, for example, suggest that the average number of incidents of workplace violence grew from 1 million incidents annually during the years $1987-1992$, to 2 million incidents annually during the years $1992-1996$, despite a 21 percent overall decline in the rate of workplace violence from 1995 to $1996 .{ }^{13}$

Beyond attempting to quantify the level of workplace violence occurring each year, early studies of workplace violence have primarily focused on dangers posed by deranged or unstable coworkers, the establishment of a profile of workplace violence victims, and the generation of behavioral and environmental warning signs. ${ }^{14}$ Three important findings have emerged from these studies. First, scholars have determined that despite significant media attention paid to coworker on coworker violence, it is clients and customers who perpetrate most incidents of violence in the workplace. ${ }^{15}$ Second, and also contrary to popular opinion, it is 
estimated that only 1 percent of the total incidents of workplace violence are perpetrated by intimates or former intimates of the victims. ${ }^{16}$ Finally, these studies suggest that among the risk factors for victimization in the workplace is enhanced on-the-job responsibility. ${ }^{17}$

Interestingly, Castillo reports that this last finding is accentuated when a distinction is made between incidents of workplace violence occurring during a robbery or attempted robbery, and incidents of workplace violence perpetrated by angry clients or customers. ${ }^{18}$ UCR data support the conclusion that additional differences, such as the use of firearms during incidents of workplace violence, accompany robbery-related versus client-perpetrated incidents of workplace violence. ${ }^{19}$

Limited research has also been conducted in the area of workplace violence in public sector versus private sector settings. However, study of violence in government work settings has been extremely limited, suggesting that much remains unknown about potential differences between the two. ${ }^{20}$ Nevertheless, despite the limitations of available information, there is suggestive evidence of differences between the violence occurring in government offices and that taking place in private sector environments. Identified differences between these two settings center around the rates at which employees from each sector are victimized in the workplace, the nature of offender motivations, and the range of possible motivations inherent in each setting.

Bureau of Justice statisticians, analyzing data from the NCVS, report that public sector employees suffer disproportionately from workplace violence. Bachman reports that during the years 1987-1992, government employees constituted 18 percent of the American workforce, but accounted for 30 percent of all incidents of workplace violence. ${ }^{21}$ Warchol, analyzing data from 1992-1996, reported that while government employees constituted 16 percent of the US workforce, they suffered 37 percent of the total incidents of workplace violence. ${ }^{22}$ Both authors, however, acknowledge that the inclusion of law enforcement personnel (who suffer the highest overall rate of workplace violence) in the category of "government workers" to some degree skews the picture of how much more likely, if at all, public sector employees are to disproportionately experience incidents of workplace violence. ${ }^{23}$ Arguments over the appropriateness of including law enforcement personnel in this comparison remain contentious. Therefore, the products of workplace violence theory regarding rates of violence alone may mislead any assessment as to whether or not government workers are in fact at an increased risk of violence in the workplace.

In this regard, findings about offender motivations contributing to workplace violence in public versus private settings are far more compelling. Separating violence motivated by robbery from violence motivated by client anger results in two different pictures of workplace violence. ${ }^{24}$ In the majority of robbery-related cases of workplace violence, for example, it is probable that interaction between employees and the offender is limited to the details of the exchange of money or goods. ("Give me the money or I will shoot you.") In contrast, it is possible that customer-driven workplace violence follows a more developed interaction between the offender and the employee. (In these cases, the customer may come to feel like he has been taken advantage of, rippedoff, or mistreated after some period of dealing with the employee or the organization.)

Given the relative differences between government settings and private workplace settings with respect to the probabilities of robbery being a motive, it is likely that this distinction becomes magnified in comparisons between public and private workplace environments. (While it is obvious that government work settings can be targets of robbery, it seems likely that private workplace settings, particularly retail or food establishments, make better targets in this regard. ${ }^{25}$ ) In other words, while violence arising from both motivations can (and probably does) occur in each sector, private work settings would appear more likely to experience robbery-related violence, and government work setrings seem more likely to experience violence borne out of customer dissatisfaction. Lord's study of violence occurring in the government offices of North Carolina supports this conclusion. Lord reported that the perpetrators of violence in North Carolina's government work settings were primarily clients or customers. ${ }^{26}$ Implications of this magnification are likely to include the possibility that when it comes to public administrators, on-the-job tesponsibility is a more significant predictor of workplace violence than in the private sector. Lord's study also supports the possibility that public employees with greater responsibility suffer from workplace violence at a higher rate than others. ${ }^{27}$ At a minimum, while this possibility does little to help establish whether or not government workers are at an increased risk of violence overall, it does seem to suggest that government workers are at risk of a different type of workplace violence altogether.

This last possibility is enhanced by findings about the range of possible offender motivations that may predicate violence in public versus private workplace settings. While the 
relationship berween antigovernment sentiments and violence in the government workplace has gone largely unexplored, research that has touched on this connection seems to indicate that antigovernment and anti-bureaucracy sentiments may contribute to violence against individual government workers. Two studies in particular point to the relevance of this connection. First, as a product of a case study of violence occurring in government offices in the state of North Carolina, Lord concluded that customers or elients of the government may be less inhibited with respect to the use of violence if they depersonalize their victims (government employees) as "bureaucrats." ${ }^{2 k}$ Second, a workplace violence typology developed by the United States Postal Service includes tertorism as a category of workplace violence. ${ }^{29}$ While the typology fails to elaborate on the consequences of terrorism for the government workplace, and while an alternate typology (developed jointly by the state of California and the Occupational Health and Safety Administration ${ }^{30}$ ) remains the dominant model among workplace violence researchers, the inclusion of terrorism in the first model suggests that some researchers, and particularly researchers working within the government, are considering the linkages between antigovernment sentiments and violence in the government workplace.

The possibility that acts of terrorism or antigovernment sentiments contribute to violence in the government workplace sets public sector personnel apart from their private sector counterparts, who are unlikely to experience the direct effects of either one. Further, if antigovernment sentiments or activity are added to the list of possible motives underlying violence in the government workplace, it seems that public sector employees are not only potentially at risk for different types of workplace violence, but also from additional types of workplace violence than their private sector counterparts. In other words, while it is likely that violence in the government workplace can (to different degrees) spring from all of the motivations that underlie violence in the private sector, violence in the government workplace can be galvanized by one additional motive (the antigovernment motive) not shared by the private sector. In this sense, particularly in light of the increasing attention being paid to the antigovernment movement and antigovernment sentiments in general, the fact that workplace violence theorists and public administration theorists alike have largely overlooked this difference seems particularly astounding.

\section{Why Study the Forest Service?}

It could be argued that Forest Rangers are a population illsuited as a focus for a study abour violence in the work- place, particularly as the "workplace" of most USFS rangers is hardly typical of government employees. Certainly, this is a point that has its merits. It is true that most government employees do not go to work every day in the forest, do not spend the bulk of their day traveling (usually alone) over large masses of land, and do not routinely carry weapons in the course of their employment. Further, it is likely that these differences could account for some of the discrepancies, if such discrepancies exist, between the violence experienced by rangers and that experienced by government workers employed in other, less exotic, environments. However, in other respects, a compelling case can be made that those employed by the Forest Service as rangers serve as an adequate proxy for the population of public administrators.

Forest rangers are employed at the ground level of government (and hence, are likely to serve the public directly), exercise discretion in matters regarding the allocation of goods and services to individual members of the public, and, within the course of their employment, concern themselves with a wide variety of activities (in this case, ranging from recreation administration to land management, law enforcement, biology, zoology, and so on). If, as Appleby suggests, what sets government work apart from all others is that it is broad in its scope, subject to public accountability, and possessed of a character oriented toward public service, ${ }^{31}$ the activities of forest rangers certainly qualify as representative of government work. Additionally, if, as current information about workplace violence seems to suggest, risk of violence in the workplace is associated with increased responsibility and contact with the public, study of government employees such as forest rangers (who are accurately characterized by both of these attributes) will generate more reliable results than a study of government employees who lack either responsibility or direct contact with the public.

Additionally, one could add that focus on the Forest Service eliminates the pitfalls of studying a historically hated agency. For instance, violence perpetrated against the taxman, solely because of the nature of his job, might be more prevalenr and/or severe than that directed at other government or private sector employees. Further, while it is not reasonable to assume that simply because an agency has had a decent rapport with the public its employees will be protected from citizen aggression, it might be sensible to speculate that employees from "favored" bureaucracies will not find themselves at a higher risk for workplace violence, at leasc that emanating from their constituents. In this sense, in light of the fact that the Forest Service has traditionally been well received by the public, ${ }^{32}$ a study of 
rangers may be more reliable than a study of some other, more despised, population of government employees.

Finally, it can be argued that the study of forest rangers is advantageous due to their visibility as government employees. Donning distinctive uniforms and driving vehicles clearly emblazoned with the agency's insignia, forest rangers stand out in their environment as not only the resident authority, but as potent symbols of government. At a minimum, this suggests that uniformed forest rangers are not typically mistaken for someone they are not. At a maximum, it may make rangers easy prey if persons with antigovernment motives are in search of a target. Regardless, when violence is perpetrated against rangers of the Forest Service, it is unlikely that the perpetrator of the violence is unaware of the identity of his victim. In this sense, a focus on rangers may be more "pure" than a focus on a population of government workers that is less identifiable (for example, those who dress in typical "business" attire) because it disallows as much as possible for the potential that confusion about the identity of the victim entered into the violent transaction (at least during incidents arising from motives other than those connected to service delivery when we can assume that the identity of the victim is already apparent to the victimizer).

In short, then, forest rangers make an acceptable population for study for at least three reasons. First, the wide range of activities undertaken by rangers guards against the possibility that, like in the case of traditional law enforcement personnel, violence is overwhelmingly connected to the very mission of these government employees. Additionally, the range of activities undertaken by rangers also works to expand the number of potential contacts they will have with the public, which is central to testing the existing theories about violence in the workplace. Second, the fact that rangers have been historically well received by the American public operates to control for the possibility that if differences between these government employees and employees of the private sector are uncovered, these differences can be attributed to a popular dislike of the agency. Finally, the unsubtle visibility of forest rangers works to minimize the likelihood of their anonymity as victims and maximize their conspicuity for perpetrators operating with antigovernment motives. In essence, their visibility may be of aid in sorting out motives against these federal employees should antigovernment intentions be among them.

\section{A Case Study of the United States Forest Service}

\section{Methodology}

Data describing violence in the workplace of the USFS was collected from information received directly from the USFS under the Freedom of Information Act (FOIA), as well as from media accounts. The fact that media accounts of violence against rangers have been located by the author that are not accounted for in Forest Service data suggests that reporting from individual rangers to Forest Service authorities is incomplete and that underreporting may be a problem. The fact that Forest Service reports appear to be incomplete, in addition to the small sample size that the reports generate, suggests reason for cautious generalization of the following findings.

This analysis is based on all reported incidents of violence against rangers (both from the Forest Service itself and from media accounts) during the years $1994-1996$. These three years were selected as a focus for a number of reasons. First, given that the violent crime rate in the United States began to decline in 1995, inclusion of 1994 data should begin to test the relationship between violence against rangers and the national crime rate. Should the pattern of violence against rangers fail to mirror fluctuations in the national violent crime rate, variations uncovered between the two may be suggestive of a difference between these public employees and victims of violence in general. This relationship, as well as potential differences between the amount of violence experienced by rangers and that occurring in the private sector, should be further tested by the inclusion of 1996 data, as workplace violence statistics from the NCVS report a dramatic decline in the number of incidents occurring in the general population between 1995 and 1996 . Finally, inclusion of the years immediately preceding and immediately following the bombing in Oklahoma City (which antigovernment scholars mark as the high-point of antigovernment activity in the United States ${ }^{33}$ ) may make it possible to begin to comment about the relationship between violence against rangers and antigovernment activity, an area that has thus far been grossly overlooked by workplace violence and public administration scholars.

\section{Findings}

In sum, sixty-four incidents of workplace violence, including overt threats of violence, were located for the threeyear focus period defined by this study. Of these sixty-four incidents, twenty were assaults (representing 31.3 percent of the total sample), seven were bombings (10.9 percent of the total sample), two were arsons (accounting for 3.1 per- 
cent of the total), one incident involved the murder of a ranger (representing 1.6 percent of the total sample), there were seven "property" crimes (10.9 percent of the total sample) and twenty-seven incidents involved threats of violence. Threats accounted for 42 percent of the total incidents in the sample. For the purposes of this study, property crimes were included in the sample because each of the specific incidents consisted of either vehicle tampering (cut brake lines, etc.) that posed a direct threat to the health and safety of Forest Service personnel, or graffiti which made explicit threats against the Forest Service or individual rangers.

Of the sixty-four incidents located for this time period, only two were reported during 1994. In 1995, there were thirtyfive reported incidents, and in 1996, the total number of reported incidents was twenty-seven. Statistical analysis reveals that 75 percent of the incidents took place in the six out of ten regions located in the western half of the United States. Concentration of these incidents in the west may suggest a connection between violence against rangers and land-use disputes or antigovernment activity, both of which

\section{Figure 1}

Local Challenges to the Forest Service

In the western United States, where regulations on land-use are often met with arduous opposition and pockets of county-power advocates have developed, the authority of Forest Service personnel has been openly challenged, sometimes violently, by local political officials and law enforcement personnel.

- In Ely, Nevada, the sheriff has authored letters to Forest Service personnel stating that he no longer recognizes the authority of the agency.

- Local law enforcement officers in Clearwater, Arizona have threatened rangers with arrest for enforcing land-use and grazing regulations.

- Sheriff's office personnel in Nye County, Nevada have kept Forest Service investigators from interviewing suspected law-breakers. The Forest Service personnel were told that interrupting their investigation was necessary to keep them safe from an "angry public."

- Also in Nye County, Nevada, a county commisionner chased two rangers off a Forest Service road. The commissioner, accompanied by armed men, was illegally driving a bulldozer through the Toiybe National Forest. This incident followed the issuance of a county order rescinding the legal authority of the Forest Service within Nye County boundaries and reserving National Forest land located within its borders for local control. are overwhelmingly more prevalent in the western United States than in other regions of the nation. However, the significance of this finding may be tenuous given that the vast majority of USFS territory is also located in the western United States. Cross tabulation revealed no significant relationship between the types of incidents directed at rangers and the locations where the incidents took place. However, this finding also should warrant caution given the small number of incidents reported, particularly in 1994.

As the data pertaining to these three years reveals, there was a substantial increase in the reported number of incidents of workplace violence between 1994 and 1995. In fact, there were nearly eighteen times as many incidents perpetrated in 1995 as in the previous year. The data also indicate that there was a 22 percent decrease in the number of incidents reported from 1995 to 1996, but that there were still fourteen times as many incidents reported in 1996 as there had been in 1994.

The dramatic changes in the frequency of incidents reported during these years becomes even more apparent when the relationship between the dates of these incidents and the timing of the Oklahoma City bombing is analyzed. Of the incidents reported during these three years, only seven of them (10.9 percent of the total) occurred during the sixteen months before the bombing. Fifty-one of the sixty-four reported incidents (or 80 percent of the total) occurred during the twenty months following the bombing, and 39 percent of the total number of incidents of violence perpetrated against Forest Service personnel took place in the final eight months of 1995 alone, the months directly following the bombing in Oklahoma City. Included in the sample were a total of six incidents $(9.4$ percent of the sample) known to have taken place in 1995 , but for which a relationship to the date of the bombing could not be discerned due to the way in which the incidents were reported. However, even if these six incidents were assumed to have taken place prior to the bombing, the percentage of events preceding the disaster in Oklahoma City would only amount to 20 percent of the total.

Prior to the Oklahoma City bombing, there were two reported threats, two bombings, two property crimes, and one assault reported in the available data, all of which were carried out in one of two Forest Service regions. Following the bombing (during the remainder of 1995 and all of 1996) there were a reported twenty threats, nineteen assaults, two arsons, one murder, five property crimes, and four bombings spread among eight Forest Service regions (the total number of regions represented in the sample). The dra- 
matic increase in both the number of incidents reported after the bombing and the violence of incidents reported after the bombing suggests the possibility-of a relationship between the rise in antigovernment sentiments that surrounded the Oklahoma City bombing and reported violence against forest rangers. However, the precise nature of that relationship is unknown. It is probable that either an actual increase in the number of assaults against rangers or an increase in the frequency with which these incidents were reported could account for the dramatic number of incidents attributed to the months following the bombing. Cross tabulation of the type of incidents reported and the dates of reported incidents revealed no significant relationships except for the huge increases in the diversity and number of incidents reported after the bombing.

Examination of Forest Service data from these three years also generated a picture of the motives underlying the violence perpetrated against these public employees. Incidents of violence against rangers were separated into categories based on the motives underlying each incident. Data on these motives were discerned from information taken from the description of the incidents in media accounts, as well as from the comments section of the documents obtained via FOIA.

Of the sixty-four incidents reported, one incident occurred during the course of a burglary of a ranger station (representing 1.5 percent of the total), two incidents were linked to the enforcement of recreation regulations (representing 3 percent of the total sample), seven incidents sprang from disputes related to the law-enforcement activities of forest rangers (accounting for 11 percent of the total sample), ten incidents were characterized by distinct antigovernment motives (amounting to 16 percent of the total sample), and 15 incidents were motivated by disputes over land-use rules and regulations (accounting for 23 percent of the sample).

For the remaining 29 incidents ( 45 percent of the total sample) clear motives could not be established. However, given the relatively high number of anonymously perpetrated incidents (shots fired from an unknown location toward an individual ranger, anonymous threats called into Forest Service facilities, etc), the number of unaccountedfor incidents is probably unsurprising. Further, it is impossible to speculate what the motives behind these anonymous, unaccounted-for incidents might be. It is likely that any number of motives could be at work in these instances.

The Tim Tibbets story is a perfect example of this unclassifiable violence. After explaining the Endangered
Species Act at a public forum in Phoenix, Arizona, Ranger Tibbets was threatened by a man in attendance who stated that he would "blow [the ranger's] head off." While it is possible that the man was a cattle-rancher upset that the enforcement of the Endangered Species Act might limit the access of public land by his herd, in which case this threat could be said to have been motivated by land-use issues, it is also plausible that the individual making the threat was angered by what he interpreted as government overreach through the Act, in which case the incident could be said to spring from antigovernment motivations. Additionally, it is conceivable that neither of these possibilities accurately captures the motives of the man who threatened Ranger Tibbets. It is also possible, for example, that the man had a long-standing personal vendetta against the ranger (although no such evidence was included in the Forest Service report on the incident), or that the man may be attempting to "get back" at the ranger for a ticket he was issued over either a recreation or traffic violation in the forest (again, no evidence of either possibility was found in the report). While it is likely that only the individual making the threat will ever have access to information about his motives, this incident is a perfect example of the type of seemingly unclassifiable violence being perpetrated against forest rangers.

Given the impossibility of commenting on the incidents motivated by unknown incentives, despite the fact that these incidents are every bit as shocking and important as their counterparts, the remainder of this discussion will focus on the incidents for which clear motives were able to be discerned. These motives underlying the incidents that could be categorized are extremely clear. For example, incidents motivated by land-use disputes mainly arose in the areas of logging, grazing, and mining. The example of a female timber sale administrator threatened with a branding hammer after she pointed out some incorrectly branded logs is illustrative of this type of motivation, as is the ranger who is threatened after finding an individual working on a revoked mining claim. Recreation and law enforcement motives are also readily assessable. For example, the ranger assaulted after he confronts the passengers of a quad-runner not wearing safery helmets, and the ranger who is choked after stopping to assist a motorist with a disabled vehicle, are clearly indicative of these two respective motives. Finally, incidents underlied by antigovernment motives (or at least incidents couched by the offender in overt antigovernment language) were also clearly discernable within the sample. Threatening, antigovernment graffiti on Forest Service property, threats made by members of a local militia to arrest forest rangers for "crimes against the people," and the in- 
vocation of Ruby Ridge, Waco, and Oklahoma City during threatening phone calls made to Forest Rangers all fall into this final category.

\section{Conclusions: What Does Violence Against Rangers Suggest?}

Analysis of the violence perpetrated against Forest Service rangers lends support to the conclusion that violence waged against government employees is significantly different than violence being perpetrated in private sector work settings. The demographics of the violence directed at rangers are, for example, different from the demographics of workplace violence uncovered by the NCVS, as well as from those constituting the national violent crime rate. While this study uncovered a decline in the number of incidents occurring between 1995 and 1996 that closely mirrors the 21 percent decrease suggested by NCVS data, as well as the similar decline in the national violent crime rate, no parallel could be drawn between either NCVS data or data on the national crime rate and the incredible increase of incidents directed at rangers between 1994 and 1995. Additionally, the fact that the number of incidents directed at rangers remained fourceen times higher in 1996 than in 1994, despite the decrease from the year before, is significantly dissimilar from NCVS data, or data describing the national violent crime rate.

Additionally, distribution of the motives underlying the violence perpetrated against forest rangers during these three years seems to support the theses of Lord and Castillo. In particular, it is clear that the incidents comprising this sample were largely not motivated by robbery. Additionally, the fact that the largest portion of the violent incidents directed at forest rangers (38 percent of the total sample) were motivated by disputes with "customers" during distinctly workrelated interactions (interactions tied to the mission of the Forest Service: recreation, land-use, and law enforcement) suggests, as do Lord and Castillo, that customer or client anger is a significant contributor to violence in this public sector workplace. Further, the fact that the violence perpetrated against rangers took place largely within a context of the enforcement of rules and regulations, as opposed to say, in situations where rangers were collecting campground fees or issuing passes to vehicles entering national forests, suggests limited support for the thesis that enhanced responsibility is correlated with an increased risk of violent victimization in this government workplace, as both Lord and Castillo assert.

Finally, the significant number of incidents in this study found to be motivated by antigovernment sentiments lends credence to the idea that the public sector workplace is vulnerable to at least one variety of workplace violence above and beyond the varieties of violence occurring in private work settings. Further, the number of incidents in this sample that appear to be incited by antigovernment motives suggests that vulnerability to this type of violence is perhaps greater among public sector employees than was previously assumed. The fact that scholars have not investigated this seemingly intuitive possibility more thoroughly is perhaps indicative of a perception that antigovernment violence is something more rare and spectacular than these data indicate.

On the contrary, perhaps the single most significant suggestion this analysis can offer is the possibility that antigovernment violence is not some rarity confined to the dramatic bombing in Oklahoma City, but rather is a reality that punctuates the working conditions of public administrators, at least of forest rangers, on nearly a day-to-day basis. If this suggestion is borne out by additional research, it is a distinct possibility that the differences between violence perpetrated against private sector employees and public administrators is not only significant, but deeply symbolic in ways which are tied intimately to our notions of public service. In that respect, rangers of the United States Forest Service may well be ahead of theorists with regard to understanding the contours of this phenomenon. To date, rangers (particularly those working in the western United States) have attempted to quell the violence they experience on the job by removing their uniforms, and working as much as is possible absent the trappings and symbols of government. ${ }^{34}$

\section{Notes}

' Bureau of Justice Statistics (Crime Data Brief), National Crime Victimization Survey: Workplace Violence, 1992-1996, 1.

2 PEER Press Release, PEER, 1 October 1999 <www.peer.org/press/ 43.htm),

"Paul Appleby, "Government is Different," Classics of Public Administration (Fort Worth: Harcourt Brace College Publishers, 1997).

${ }^{4}$ Graham T. Allison, "Public and Private Management: Are They Alike in All Unimportant Respects?" Classics of Public Administration (Fort Worth: Harcourt Brace College Publishers, 1997).

'Marc Holzer and Kathe Callahan, Government at Work: Best Practices and Model Programs (Thousand Oaks; Sage Publications, 1997).

"Allison, 387. 

7Frederick C. Mosher, "Democracy and the Public Service: The Collec-
tive Services," Classics of Public Administration (Fort Worth: Harcourt Brace
College Publishers, 1997).

${ }^{8}$ Charles T. Goodsell, The Case for Bureancracy: A Public Administration Polemic (Chatham: Chatham House Publishers, Inc, 1994).

"Stephen Barret, "Protecting Against Workplace Violence," Public Management 79:12.

${ }^{11}$ Cheryl Simrell King and Camilla Stivers, Government is Us: Public Administration in an Antigovernment Era (Thosand Oaks: Sage Publications, 1998).

"See Bureau of Justice Statistics (Crime Data Brief), National Crime Victimization Survey: Workplace Violence, 1992-1996 and Bureau of Justice Statistics (Crime Data Brief), National Crime Victimization Survey: Violence and Theft in the Workplace, 1.

${ }^{12}$ Bureau of Justice Staristics (Crime Data Brief), National Crime Victimization Survey: Workplace Violence, 1992-1996, 1.

1.3 Ibid.

${ }^{14}$ Sandra L. Heskett, Workplace Violence: Before, During, and After (Boston: Butterworth-Heinemann, 1996).

${ }^{15}$ Bureau of Justice Statistics (Crime Data Brief), National Crime Victimization Survey: Workplace Violence, 1992-1996, 1.

"I Ibid.

${ }^{17}$ Violence in the Workplace, Centers for Disease Control, 1 August 1999 <www.edc.gov/niosh/violnonf.htm>.

${ }^{18}$ Ibid.

${ }^{19}$ Bureau of Justice Statistics (Crime Data Brief), National Crime Victimization Survey: Violence and Theft in the Workplace, 1.

20 Violence in the Workplace, Centers for Disease Control, 1 August 1999 <www.cdc.gov/niosh/violnonf.htms.

${ }^{21}$ Bureau of Justice Statistics (Crime Data Brief), National Crime Victimization Survey: Violence and Theft in the Workplace, 1.

${ }^{22}$ Bureau of Justice Statistics (Crime Data Brief), National Crime Victimization Survey: Workplace Violence, 1992-1996, 1.

${ }^{23}$ See Bureau of Justice Statistics (Crime Data Brief), National Crime Victimization Survey: Workplace Violence, 1992-1996, and Bureau of Justice Statistics (Crime Data Brief), National Crime Victimization Strvey: Violence and Theft in the Workplace, 1.

${ }^{24}$ Violence in the Workplace, Centers for Disease Control, 1 August 1999 $<$ www.cdc.gov/niosh/violnonf.htm>.

${ }^{25}$ Workplace Violence Statistics, Nacional Center for Victims of Crime, 1 August 1999 <www.nvc,org/stats/workplac.htm>.

2.6 Vivian B. Lord, "Characteristics of Violence in State Government," Journal of Interpersonal Violence 13 (1998): 489-503.
${ }^{27}$ Lord, 492.

${ }^{28}$ Lord, 495.

${ }^{20}$ Heskett, 17.

${ }^{30}$ Heskett, 17.

${ }^{31}$ Appleby, 125.

${ }^{32}$ Michael R. Pendleton, "Crime, Criminals, and Guns in 'Natural Settings': Exploring the Basis for Disarming Federal Rangers," The American Journal of Police 10 (1996): 181-193.

33 Brad Knickerbocker, "Antigovernment Ire Targets Local Officials." The Christian Science Monitor, 22 August 1997.

${ }^{34}$ King and Stivers, 61

\section{Bibliography}

Appleby, Paul. "Government is Different." In Classics of Public Administration, Eds. Jay M. Shafritz and Albert C. Hyde. Fort Worth, Texas: Harcourt Brace College Publishers: 122-126.

Allison, Graham T. "Public and Private Management: Are They Alike in All Unimportant Respects?" In Classics of Public Administration. Eds. Jay M. Shafritz and Albert C. Hyde. Fort Worth, Texas: Harcourt Brace College Publishers: 383-400.

Barret, Stephen. "Protecting Against Workplace Violence." Public Management 79, 8:9-12.

Bureau of Justice Statistics Crime Data Brief. National Crime Victimization Survey: Violence and Theff in the Workplace. Washington, DC: GPO, 1994.

Bureau of Justice Statistics. National Crime Victimization Survey: Workplace Violence, 1992-1996. Washington, DC: GPO, 1997.

Department of Occupational Health and Safety (Special Publication. CallOSHA Guidelines for Workplace Safety. Washington, DC: GPO, 1994.

Goodsell, Charles T. The Case for Bureancracy: A Public Administration Polemic (Third Edition). Chatham, New Jersey: Chatham House Publishers, Inc, 1994.

Heskett, Sandra L. Workplace Violence: Before, During, and Affer. Boston: Butterworth-Heinemann, 1996.

Holzer, Marc, and Kathe Callahan. Government at Work: Best Practises and Model Programs. Thousand Oaks, California: Sage Publications, 1997.

King, Cheryl Simrell and Camilla Stivers, Government is Us: Public Administration in an Antigovernment Era. Thousand Oaks, California: Sage Publications, 1998.

Knickerbocker, Brad. "Antigovernment Ire Targets Local Officials." The Christian Science Monitor, 22 August 1997. 
Lord, Vivian B. "Characteristics of Violence in State Government," Joumal of Interpersonal Violence 13 (1998).

Meadows, Robert J. Understanding Violence and Victimization. Upper River, New Jersey: 1998.

Mosher, Frederick C. "Democracy and the Public Service: The Collective Services," In Classics of Public Administration, Eds. Jay M. Shafritz and Albert C. Hyde. Fort Worth, Texas: Harcourt Brace College Pub lishers.

PEER Press Release. PEER. 1 October $1999<$ <ww.peer.org/press/ 43.htm>.

Pendleton, Michael R. "Crime, Criminals, and Guns in 'Natural Settings': Exploring the Basis for Disarming Federal Rangers," The American Journal of Police 10 (1996).

Violence in the Workplace. Centers for Disease Control. 1 August 1999 <www.cdc.gov/niosh/violnonf.htm>.

Workplace Violence Statistics, National Center for Victims of Crime. I August 1999 <www.nvc.org/stats/workplac.htm>. 